\title{
Obituary
}

\section{Dr Norman Allen}

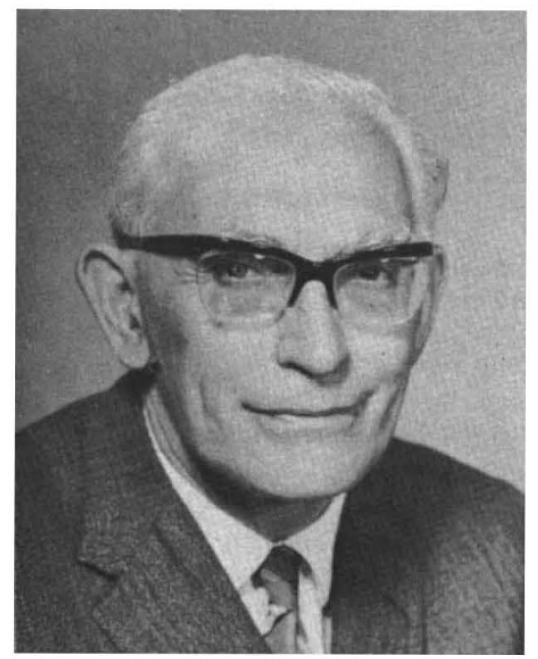

Norman Percy Allen, CB, FRS, died on February 23, 1972, at his home in Weybridge. From 1944 until 1967 he was Superintendent of the Metallurgy Division of the National Physical Laboratory, and in 1966, when the Materials Group was formed at the National Physical Laboratory, he was made the first head of the group and appointed Deputy Director. He retired from the post of Deputy Director at the end of 1967.

Allen was born in 1903 in Wrexham, Denbighshire, and graduated in metallurgy at the University of Sheffield, obtaining the M.Met in 1924. He spent the following five years at University College, Swansea, in the company of a number of others who have subsequently become famous in the metallurgical world. He worked there for the British Non-Ferrous Metals Research Association and afterwards at the University of Birmingham, where he became a senior lecturer and made important studies of gases in metals, particularly the causes of porosity in copper and silver ingots. For this work he was awarded the DSc degree in 1934.

In 1935 Allen went to the Mond Nickel Co where he was senior research metallurgist, engaged on a variety of work, which in later years took place during the war and hence was not published. Two important advances during this period were made. The first was the understanding of transfoimations in alloy steels and their influence on the mechanical properties of the product. The differences between low alloy and plain carbon steels were revealed by measurements of transformation velocities, and following this, the design of steels in terms of their hardenability became possible. The other achievement was the development of the first nimonic creep-resisting alloys which were used in the hottest parts of the first jet engine.

Allen joined the NPL in 1944, when he was appointed Superintendent of the Metallurgy Division in succession to Dr Sykes (now Sir Charles Sykes). During his superintendency many important advances in alloy design and in the utilization of new metals took place. The division made considerable contributions on the metallography of uranium and the preparation of beryllium, before the AEA work at Harwell got started, and the deformation and fracture of iron and its alloys. The application of electron microscopy to the study of metals also took place under Allen and his interest in electron microscopy continued until his death. $\mathrm{He}$ was particularly instrumental in starting the work on measurement of surface and grain boundary energies, because he believed that the grain boundary energy was a controlling parameter for the work of fracture of high strength steels. He also started important work on the soft X-ray spectroscopy of metals and the mechanical properties of alloys at elevated temperatures, including the creep of steam turbine materials, the thermal fatigue of gas turbine alloys, the thermodynamics of alloys and the metallurgy of titanium.

Allen had a keen insight into materials and was instrumental in setting up the Materials Group at NPL, which included the work not only on metals but also that on inorganic materials, plastics and on the physical properties of a number of chemical substances.

His interest in the development of steel remained, however, and during his period at NPL work was carried out which demonstrated the high toughness and high yield strength which could be obtained by lowering the carbon content of normal mild steel. This work, and the emphasis on the importance of increased quantities of manganese were instrumental in BISRA's subsequent success in patenting, throughout the world, special processes for the controlled rolling of mild steel.

For his work on alloy steels and the development of their engineering properties Allen was elected to the Royal Society in 1956 . In 1962 he recognized the potential importance of the development in the United States of high field superconductors based on the niobiumtin system and was instrumental in setting up in Britain a collaborative project, sponsored by the government, which operated for a number of years and made possible the production of superconducting materials. The management of the Superconductivity Project was carried out under his direction and it coordinated the efforts of industry, universities and government. As a member of many government committees concerned with the application of metallurgy in defence and the nationalized industries, Allen exerted a very considerable influence over the development of materials in this country throughout the fifties and early sixties.

In 1961 Allen was President of the Institution of Metallurgists and was awarded the CB in 1966 . He was awarded the Osmond Medal of the French Society of Metallurgy and many honorary degrees from universities in Britain and abroad. $\mathrm{He}$ received the Bessemer Gold Medal of the Iron and Steel Institute in 1965 and the Platinum Medal of tive Institute of Metals in 1967. He was also honoured by the Italian Association of Metallurgy, and achieved the rare distinction in the last year of his life of being elected a Fellow of the Institute of Metals.

Allen was always a man of definitely held views, and metallurgists and colleagues throughout Britain, as well as in America and Europe, will miss his whole-hearted method of assertion and his generous enjoyment of a thoroughly good scientific argument.

\section{Professor Peter Preiswerk}

Professor Peter Preiswerk died on January 28, 1972, a few days before his retirement at the age of 65 from the European Organization for Nuclear Research (CERN) at Meyrin, near Geneva.

Preiswerk was born at Basle, Switzerland, in 1907. As a student he attended Basle University and later the University of Berlin where his teachers included many of the great physicists of that time: Nernst, Planck, von Laue, Schrödinger and Bothe. He was awarded his doctorate in 1933, after his return to Basle University.

In 1934 he joined the laboratory of Madame Curie in Paris and became a collaborator of Frédéric and Irène Joliot who had just announced their discoveries in artificial radioactivity. Later he worked on slow neutron physics with 